\title{
Evaluation of Motor Coordination and Antidepressant Activities of Cinnamomum osmophloeum ct. Linalool Leaf Oil in Rodent Model
}

\author{
Hui-Ting Chang ${ }^{1, *}$, Mei-Ling Chang ${ }^{2}$, Yen-Ting Chen ${ }^{1}$, Shang-Tzen Chang ${ }^{1}$, Fu-Lan Hsu ${ }^{3}$, Chia-Chen Wu ${ }^{3}$ \\ and Cheng-Kuen $\mathrm{Ho}^{3}$
}

check for

updates

Citation: Chang, H.-T.; Chang, M.-L.; Chen, Y.-T.; Chang, S.-T.; Hsu, F.-L.; Wu, C.-C.; Ho, C.-K. Evaluation of

Motor Coordination and

Antidepressant Activities of Cinnamomum osmophloeum ct. Linalool Leaf Oil in Rodent Model. Molecules 2021, 26, 3037. https:// doi.org/10.3390/molecules26103037

Academic Editor: Hinanit Koltai

Received: 8 March 2021

Accepted: 17 May 2021

Published: 19 May 2021

Publisher's Note: MDPI stays neutral with regard to jurisdictional claims in published maps and institutional affiliations.

Copyright: (c) 2021 by the authors. Licensee MDPI, Basel, Switzerland. This article is an open access article distributed under the terms and conditions of the Creative Commons Attribution (CC BY) license (https:// creativecommons.org/licenses/by/ $4.0 /)$.
1 School of Forestry and Resource Conservation, National Taiwan University, Taipei 106, Taiwan; r05625034@ntu.edu.tw (Y.-T.C.); peter@ntu.edu.tw (S.-T.C.)

2 Department of Food Science, Nutrition, and Nutraceutical Biotechnology, Shih Chien University, Taipei 104, Taiwan; mlchang@g2.usc.edu.tw

3 Taiwan Forestry Research Institute, Council of Agriculture, Executive Yuan, Taipei 100, Taiwan; fulan40@gmail.com (F.-L.H.); chiachen@tfri.gov.tw (C.-C.W.); ckho@tfri.gov.tw (C.-K.H.)

* Correspondence: chtchang@ntu.edu.tw; Tel.: +886-2-3366-5880

\begin{abstract}
Cinnamomum plants (Lauraceae) are a woody species native to South and Southeast Asia forests, and are widely used as food flavors and traditional medicines. This study aims to evaluate the chemical constituents of Cinnamomum osmophloeum ct. linalool leaf oil, and its antidepressant and motor coordination activities and the other behavioral evaluations in a rodent animal model. The major component of leaf oil is linalool, confirmed by GC-MS analysis. Leaf oil would not induce the extra body weight gain compared to the control mice at the examined doses after 6 weeks of oral administration. The present results provide the first evidence for motor coordination and antidepressant effects present in leaf oil. According to hypnotic, locomotor behavioral, and motor coordination evaluations, leaf oil would not cause side effects, including weight gain, drowsiness and a diminishment in the motor functions, at the examined doses. In summary, these results revealed C. osmophloeum ct. linalool leaf essential oil is of high potential as a therapeutic supplement for minor/medium depressive syndromes.
\end{abstract}

Keywords: antidepressant effect; Cinnamomum osmophloeum; linalool; motor coordination activity

\section{Introduction}

Cinnamon plants (Cinnamomum species, Lauraceae) are one of the important natural product resources from forests and are used as the well-known spice and ethnopharmacological remedy. Cinnamomum osmophloeum Kanehira is one of the traditional medicinal plants; its bark is used as a folk medicine for treating colds and improving gastrointestinal function. Essential oils are distilled from its leaves, bark and seeds for various purposes. The leaves are common ingredients in herbal teas and a classic spice in the rural cuisine. Recent studies have confirmed that natural products from C. osmophloeum exhibit antibacterial [1], xanthine oxidase inhibitory [2], insecticidal [3], antioxidant [4], antianxiety [5] activities, etc.

Depression is a mental disorder that involves physical and mental conditions, often with pessimistic moods and negative emotions, causing sleep difficulties and a decline in bodily functions, and it is one of the most important diseases that cannot be ignored. Many studies revealed the usefulness of St John's wort extract (Hypericum perforatum), a commercial antidepressant supplement, which can be used to soothe mild and moderate depression [6-10]. Other specific plants have also shown antidepressant activity and bioactive ingredients, such as Lavandula officinalis, Piper nigrum, Bacopa monniera, Justicia spicigera and saffron (Crocus sativus) [11-15]. Phytochemical compounds, including hyperforin, curcumin, resveratrol, and cinnamic acid, exhibit antidepressant effects [7,16-18]. 
The psychological and physical symptoms of depressive disorders are melancholy mood, fear, no motivation, changes in appetite, sleep problems, psychomotor retardation, etc. Additionally, common psychological and physical symptoms of anxiety disorders include restlessness, nervousness, irritability, uncontrollable worry, difficulty concentrating, panic, sleep disorders, fatigue, fear, etc. Depression and anxiety may occur simultaneously and have the similar symptoms. There are different signs and symptoms between depression and anxiety, and pharmacological and psychological therapies for anxiety disorders are different from depressive disorders [16,19-21].

Previous scientific findings reported that linalool, a common monoterpene present in many aromatic plant essential oils, possesses antianxiety activity, a positive effect on social interaction, and a reduction in aggressive behaviors [5,22-24]. Rare research has mentioned the antidepressant activity of linalool, and no paper has investigated the motor coordination activity and the other behavioral effects of linalool. Therefore, the aims of this study were to analyze the chemical constituents of C. osmophloeum ct. linalool leaf oil, and to validate its antianxiety activity, locomotor activity, antidepressant effect, antinociceptive activity, hypnotic effect, and motor coordination activity in mice by rodent behavioral assays. It is expected to confirm the antianxiety activity of C. osmophloeum ct. linalool leaf oil, and firstly evaluate the antidepressant effect, motor coordination activity and other bioactive properties.

\section{Results and Discussion}

\subsection{Constituent Analysis of Cinnamomum osmophloeum ct. Linalool Leaf Oil}

A schematic illustration of constituent analysis and behavioral evaluations of Cinnamomum osmophloeum ct. linalool leaf oil is shown in Figure 1. According to gas chromatographymass spectrometry (GC-MS) analyses (Figure 2), the main component of the selected C. osmophloeum leaf oil was linalool $(93.2 \%)$, followed by coumarin $(2.3 \%)$, camphor $(1.5 \%)$, $\beta$-caryophyllene $(1.2 \%)$, trans-cinnamaldehyde $(1.0 \%)$, and caryophyllene oxide $(0.8 \%)$ (Table 1). The content of the major compound, linalool, was more than $90 \%$; it revealed that the quality and stability of leaf oils from C. osmophloeum ct. linalool are consistent.

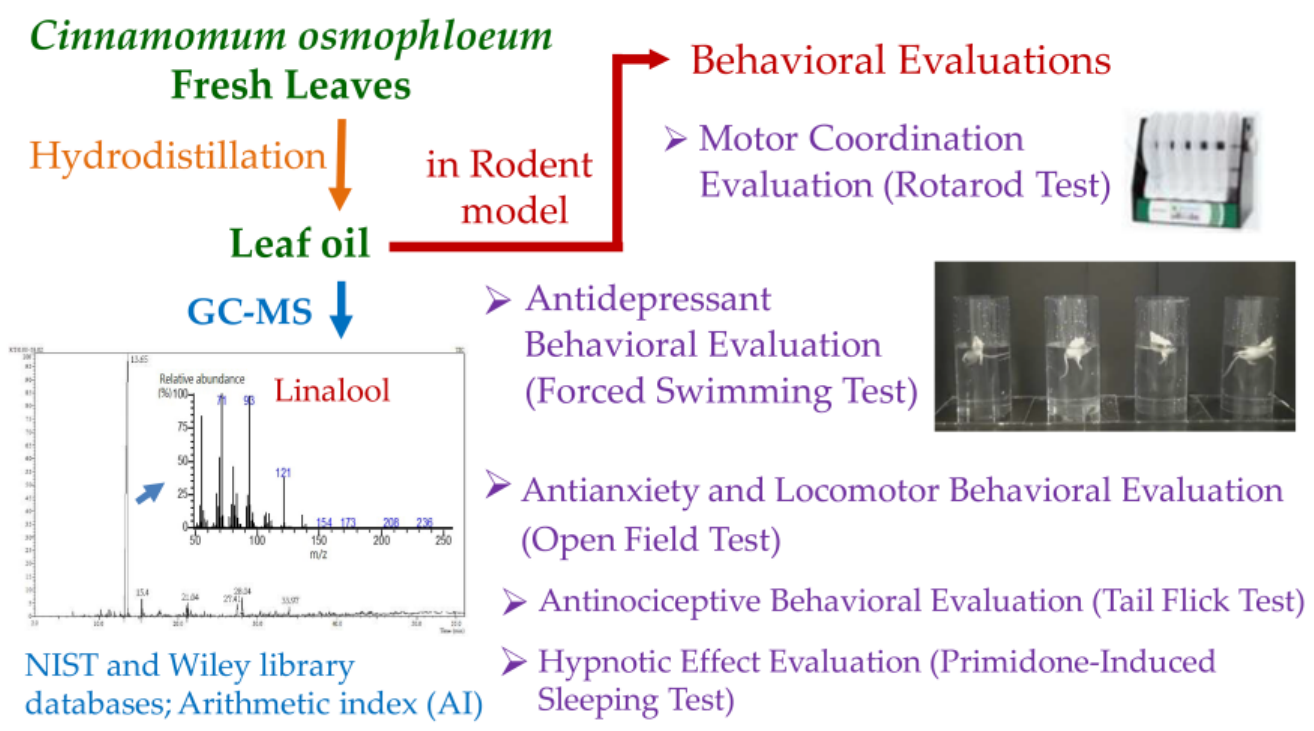

Figure 1. Schematic illustration of constituent analysis and behavioral evaluations of C. osmophloeum ct. linalool leaf oil. 


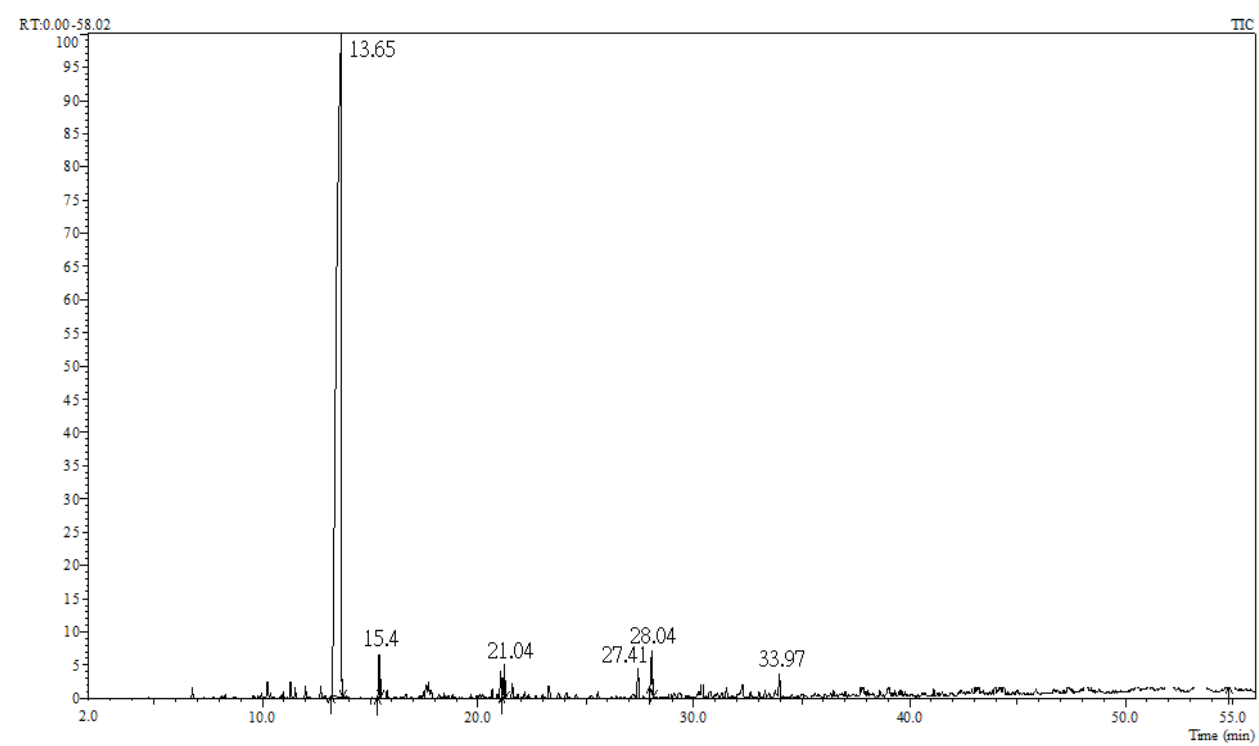

Figure 2. Gas chromatogram of C. osmophloeum ct. linalool leaf oil.

Table 1. Constituents of C. osmophloeum ct. linalool leaf oil.

\begin{tabular}{cccccc}
\hline RT & AI & Compound & Formula & $\begin{array}{c}\text { Relative } \\
\text { Content (\%) }\end{array}$ & $\begin{array}{c}\text { Identification } \\
\text { Method }\end{array}$ \\
\hline 13.65 & 1091 & Linalool & $\mathrm{C}_{10} \mathrm{H}_{18} \mathrm{O}$ & 93.2 & MS, AI \\
15.40 & 1141 & Camphor & $\mathrm{C}_{10} \mathrm{H}_{16} \mathrm{O}$ & 1.5 & $\mathrm{MS}, \mathrm{AI}$ \\
21.04 & 1264 & trans-Cinnamaldehyde & $\mathrm{C}_{9} \mathrm{H}_{8} \mathrm{O}$ & 1.0 & $\mathrm{MS}, \mathrm{AI}$ \\
27.41 & 1418 & $\beta$-Caryophyllene & $\mathrm{C}_{15} \mathrm{H}_{24}$ & 1.2 & MS, AI \\
28.04 & 1431 & Coumarin & $\mathrm{C}_{9} \mathrm{H}_{6} \mathrm{O}_{2}$ & 2.3 & MS, AI \\
33.97 & 1580 & Caryophyllene oxide & $\mathrm{C}_{15} \mathrm{H}_{24} \mathrm{O}$ & 0.8 & MS, AI \\
\hline
\end{tabular}

RT: retention time (min); AI: arithmetic index relative to $n$-alkanes (C8-C30) on a DB-5MS column.

\subsection{Effect of Leaf Oil on the Body Weight of Mice}

The body weight of the ICR mice was measured every week during the experimental period. The initial and final body weights of all mice, including the control, positive control (trazodone hydrochloride), and treatment with three doses (100, 200, and $400 \mathrm{mg} / \mathrm{Kg}$ ) of leaf oil, were in the normal ranges, as shown in Table 2. The body weight gains of the control and positive control mice increased $7.6 \pm 2.1 \mathrm{~g}$ and $7.1 \pm 1.1 \mathrm{~g}$ after 6 weeks. The body weight gains of the mice treated with three doses of leaf oil (LO100, LO200, and LO400) were $8.2 \pm 1.9 \mathrm{~g}, 6.8 \pm 2.1 \mathrm{~g}$, and $7.6 \pm 2.1 \mathrm{~g}$, respectively, with no significant difference between all groups in the statistical analysis. It reveals that $C$. osmophloeum $\mathrm{ct}$. linalool leaf oil intake did not reduce or increase the appetite of mice; leaf oil would not affect the body weight of mice.

Table 2. Effect of different doses of C. osmophloeum ct. linalool leaf oil on the body weight gain of ICR mice after 6 weeks of oral administration.

\begin{tabular}{cccccc}
\hline & Control & TH100 & LO100 & LO200 & LO400 \\
\hline Initial body weight $(\mathrm{g}){ }^{*}$ & $30.1 \pm 1.6$ & $30.4 \pm 2.1$ & $30.3 \pm 1.5$ & $30.7 \pm 1.5$ & $30.1 \pm 2.1$ \\
$\begin{array}{c}\text { Body weight } \\
\text { after 6 weeks (g) }\end{array}$ & $37.9 \pm 2.3$ & $37.2 \pm 2.2$ & $37.9 \pm 2.1$ & $38.1 \pm 3.2$ & $37.1 \pm 3.1$ \\
Weight gain (g/6 weeks)
\end{tabular}

Data are presented as mean \pm S.D. $(n=7) .{ }^{*}$ Values in the table are not significantly different at the level of $p<0.05$ according to the Scheffe's test. TH100: trazodone hydrochloride, $100 \mathrm{mg} / \mathrm{Kg}$; LO100, LO200, and LO400: leaf oil, $100 \mathrm{mg} / \mathrm{Kg}, 200 \mathrm{mg} / \mathrm{Kg}$, and $400 \mathrm{mg} / \mathrm{Kg}$. 


\subsection{Effect of Leaf Oil on the Antianxiety and Locomotor Behavior of Mice}

Table 3 shows the effect of leaf oil on antianxiety activity in mice by the open field assay. The number of entries in the central zone of the control mice was $18.00 \pm 4.47$, which was much lower than that of the mice treated with trazodone hydrochloride at a dose of $100 \mathrm{mg} / \mathrm{Kg}(31.14 \pm 3.76)$. It revealed that the treatment of trazodone hydrochloride resulted in the mice more frequently entering the central zone instead of staying in the peripheral zone in the open field test box. No significant difference in the number of entries into the central zone were found between control mice and the mice treated with leaf oil at a low dose $(100 \mathrm{mg} / \mathrm{kg})$. The number of entries into the central zone of the mice treated with the dose $(400 \mathrm{mg} / \mathrm{kg})$ of leaf oil was $31.00 \pm 3.87$, indicating that the antianxiety activity of leaf oil treatment was comparable with that of the positive control, trazodone hydrochloride, $(p<0.05)$. The number of entries into the central zone of the mice treated with leaf oil was increased and related to the treated doses. The result indicated the leaf oil has an anxiolytic effect in mice, and it is consistent with the previous studies performed by Linck et al. (2010) [22] and Cheng et al. (2015) [5].

Table 3. Effect of different doses of C. osmophloeum ct. linalool leaf oil on antianxiety activity in ICR mice by the open field assay.

\begin{tabular}{ccc}
\hline Specimen & $\begin{array}{c}\text { Number of Entries into } \\
\text { Central Zone }\end{array}$ & Total Distance Traveled (m) \\
\hline Control & $18.00 \pm 4.47^{\mathrm{a}}$ & $21.28 \pm 2.11^{\mathrm{A}}$ \\
TH100 $^{*}$ & $31.14 \pm 3.76^{\mathrm{c}}$ & $25.70 \pm 2.56^{\mathrm{B}}$ \\
LO100 & $20.71 \pm 4.79^{\mathrm{a}, \mathrm{b}}$ & $21.58 \pm 2.88^{\mathrm{A}}$ \\
LO200 & $28.71 \pm 5.22^{\mathrm{b}, \mathrm{c}}$ & $25.30 \pm 2.62^{\mathrm{B}}$ \\
LO400 & $31.00 \pm 3.87^{\mathrm{c}}$ & $24.39 \pm 2.33^{\mathrm{B}}$ \\
\hline
\end{tabular}

Data are presented as mean \pm S.D. $(n=7){ }^{*}$ : Positive control; TH100: trazodone hydrochloride, $100 \mathrm{mg} / \mathrm{Kg}$, LO100, LO200, and LO400: leaf oil, $100 \mathrm{mg} / \mathrm{Kg}, 200 \mathrm{mg} / \mathrm{Kg}$, and $400 \mathrm{mg} / \mathrm{Kg}$. Different letters (a-c and A-B) in the table are significantly different at the level of $p<0.05$ according to the Scheffe's test.

The total distance traveled in the open filed test was also calculated to identify the locomotor activity level of the test mice after different treatments, as shown in Table 3. The control mice and the mice treated with leaf oil at a low dose $(100 \mathrm{mg} / \mathrm{kg})$ showed a similar performance: the total distance traveled of both groups were $21.28 \pm 3.87$ and $21.58 \pm 2.88 \mathrm{~m}$, respectively. The significant improvement of the total distance traveled was observed in the other three groups $(p<0.05)$; the total distance traveled of these groups ranged from 24.39 to $25.70 \mathrm{~m}$. The mice treated with trazodone hydrochloride $(100 \mathrm{mg} / \mathrm{kg})$ travelled the longest distance, which demonstrated the superior locomotor activity. The higher dose of leaf oil (200 and $400 \mathrm{mg} / \mathrm{kg}$ ) produced a significant increase in the total distance traveled compared to that of the control mice, it reflects that the locomotor activity level of mice was enhanced after treatment with the high-dose leaf oil.

\subsection{Effect of Leaf Oil on the Antidepressant Behavior of Mice}

The forced swimming test is the typical and representative assay used to evaluate the antidepressant activity in rodent animals. Mahmoudi et al. (2015) reported that Feijoa sellowiana leaf extract showed the antidepressant activity in the forced swimming assay; leaf extract treatment remarkably decreased the immobility time of the male Swiss albino mice [20]. Shorter immobility time means the treated mice exhibit more vigorous and active behaviors instead of depressive symptoms in the stress environment. The immobility behavior of mice in the forced swimming test was reduced by the administration of Turnera diffusa aqueous extract; results confirmed the antidepressant effect of T. diffusa aqueous extract [25].

Figure 3 shows the immobility time of the examined mice in the forced swimming test: the latency of control group mice was $109.50 \pm 7.13 \mathrm{~s}$. The immobility time of the mice treated with trazodone hydrochloride, a prescription antidepressant, was significantly 
shorter $(39.75 \pm 3.69 \mathrm{~s})$ than that of control mice at the dose of $100 \mathrm{mg} / \mathrm{kg}$. The leaf oil also induced the considerable reduction in immobility time compared with the vehicle control, with a statistical difference $(p<0.05)$; the immobility time of the treated mice was $64.50 \pm 4.81 \mathrm{~s}$ at the dose of $200 \mathrm{mg} / \mathrm{kg}$. The antidepressant behavior of mice can be markedly improved by the oral administration of the C. osmophloeum ct. linalool leaf oil.

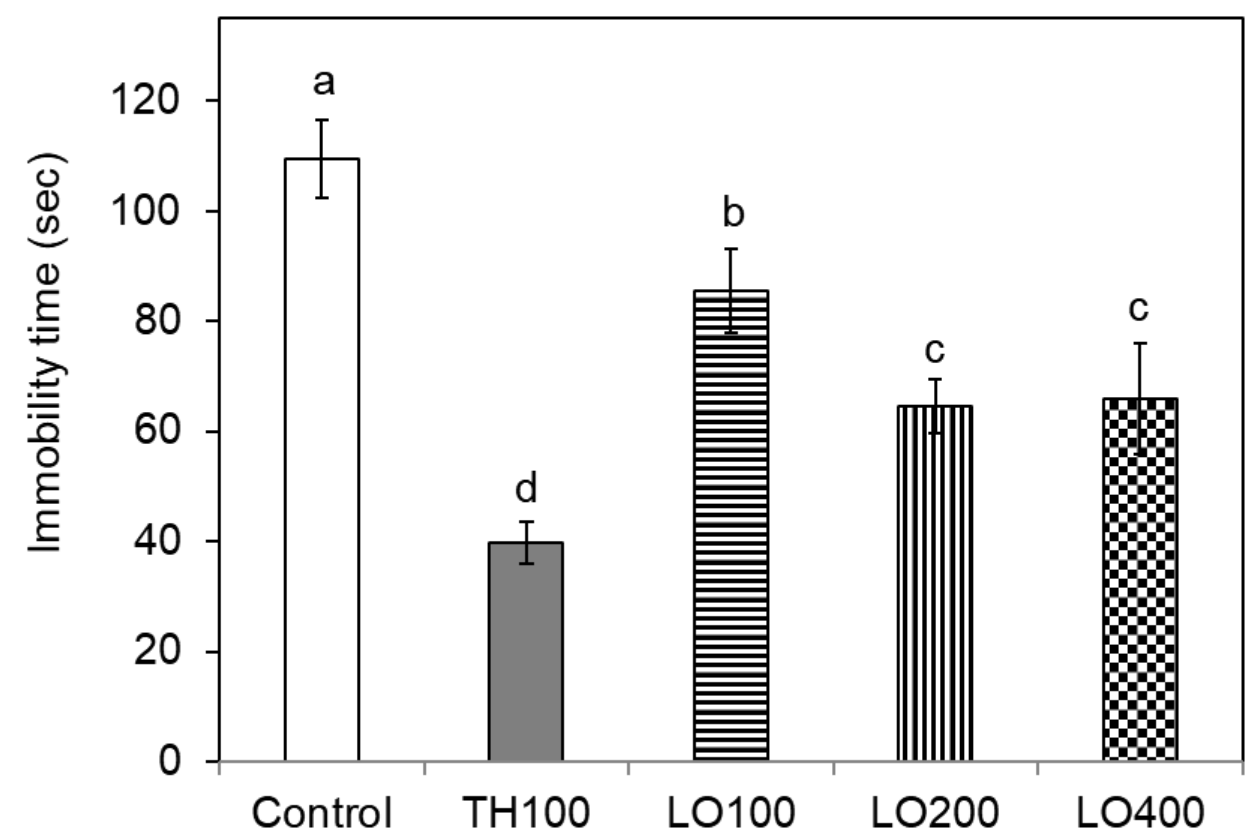

Figure 3. Effect of different doses of C. osmophloeum ct. linalool leaf oil on antidepressant activity in ICR mice by the forced swimming assay. Data are presented as mean \pm S.D. $(n=7)$; TH100: trazodone hydrochloride, $100 \mathrm{mg} / \mathrm{Kg}$; LO100, LO200, and LO400: leaf oil, $100 \mathrm{mg} / \mathrm{Kg}$, $200 \mathrm{mg} / \mathrm{Kg}$, and $400 \mathrm{mg} / \mathrm{Kg}$. Different letters (a-d) in the figure are significantly different at the level of $p<0.05$ according to the Scheffe's test.

\subsection{Effect of Leaf Oil on the Antinociceptive Behavior of Mice}

Tail flicking in rodents is a response of pain caused by the heat stimulus to measure the efficacy of antinociceptive activity. The results of the tail flick test are shown in Table 4; the tail flick time of control mice was $3.75 \pm 0.38 \mathrm{~s}$. The mice treated with trazodone hydrochloride exhibited a slight decrease in the tail flick time $(3.49 \pm 0.32 \mathrm{~s})$ without statistical significance $(p<0.05)$. No differences were found between the mice treated with different doses $(100-400 \mathrm{mg} / \mathrm{Kg}$ ) of leaf oil; the tail flick time was between $3.81-4.01 \mathrm{~s}$. The results indicated that both the leaf oil and trazodone hydrochloride did not exhibit the antinociceptive activity for the experimental mice.

Table 4. Effect of different doses of C. osmophloeum ct. linalool leaf oil on antinociceptive and hypnotic activities in ICR mice.

\begin{tabular}{ccc}
\hline Specimen & $\begin{array}{c}\text { Time (sec) } \\
\text { in the Tail Flick Test * }\end{array}$ & $\begin{array}{c}\text { Duration (min) } \\
\text { in the Primidone-Induced Sleeping Test * }\end{array}$ \\
\hline Control & $3.75 \pm 0.38$ & $55.08 \pm 4.72$ \\
TH100 & $3.49 \pm 0.32$ & $49.87 \pm 5.36$ \\
LO100 & $3.91 \pm 0.12$ & $49.91 \pm 4.59$ \\
LO200 & $3.81 \pm 0.28$ & $50.10 \pm 4.22$ \\
LO400 & $4.01 \pm 0.19$ & $52.10 \pm 5.61$
\end{tabular}

Data are presented as mean \pm S.D. $(n=7)$. TH100: trazodone hydrochloride, $100 \mathrm{mg} / \mathrm{Kg}$; LO100, LO200, and LO400: leaf oil, $100 \mathrm{mg} / \mathrm{Kg}, 200 \mathrm{mg} / \mathrm{Kg}$, and $400 \mathrm{mg} / \mathrm{Kg}$. ${ }^{*}$ Values in the table are not significantly different at the level of $p<0.05$ according to the Scheffe's test. 


\subsection{Effect of Leaf Oil on the Hypnotic Effect of Mice}

Rahimi et al. (2018) reported the hypnotic effect of the fruit and seed extracts of Lagenaria vulgaris on pentobarbital-induced sleep in mice [26]. The extracts of L. vulgaris significantly increased the sleeping duration of mice at a dose of $200 \mathrm{mg} / \mathrm{kg}$, the result revealed that the fruit and seed extracts of L. vulgaris exhibited the sleep-prolonging effect.

The results of the primidone-induced sleeping test is listed in Table 4; the duration (sleeping time) of the control mice was $55.08 \pm 4.72 \mathrm{~min}$. The mice treated with leaf oil at $100 \mathrm{mg} / \mathrm{kg}$ showed a slight reduction in the sleeping time (49.91 $\pm 4.59 \mathrm{~min})$ compared to the control, but the data of both groups were not statistically significant. The durations of the other treated mice were all lower than that of the control group, indicating that no hypnotic activity was observed for leaf oil in the primidone-induced sleeping test in none of the examined doses. Some antidepressant medicines would cause drowsiness to different extents in patients. Results from the hypnotic evaluation revealed that $C$. osmophloeum $\mathrm{ct}$. linalool leaf oil would not lead to drowsiness at the examined doses.

\subsection{Effect of Leaf Oil on the Motor Coordination Behavior of Mice}

Motor coordination activity was evaluated by the rotarod assay, as depicted in Figure 4. The duration time of the control mice remained on the rotating rod was $192.40 \pm 19.03 \mathrm{~s}$. There was no significant difference in latency to falling in rotarod between the control mice and the mice treated with the low dose of leaf oil $(100 \mathrm{mg} / \mathrm{kg})$. The mice treated with the higher doses of leaf oil ( 200 and $400 \mathrm{mg} / \mathrm{kg}$ ) showed a large increase in the time spent on the rotating rod, as compared with the positive control, trazodone hydrochloride, at the dose of $100 \mathrm{mg} / \mathrm{kg}(p<0.05)$; the duration time of these group were $293.71 \pm 12.19,290.67 \pm 14.68$, and $286.50 \pm 22.05 \mathrm{~s}$, respectively. A maximum improvement in the duration time of the mice treated leaf oil $(200 \mathrm{mg} / \mathrm{kg})$ was $52.66 \%$ compared to the control group.

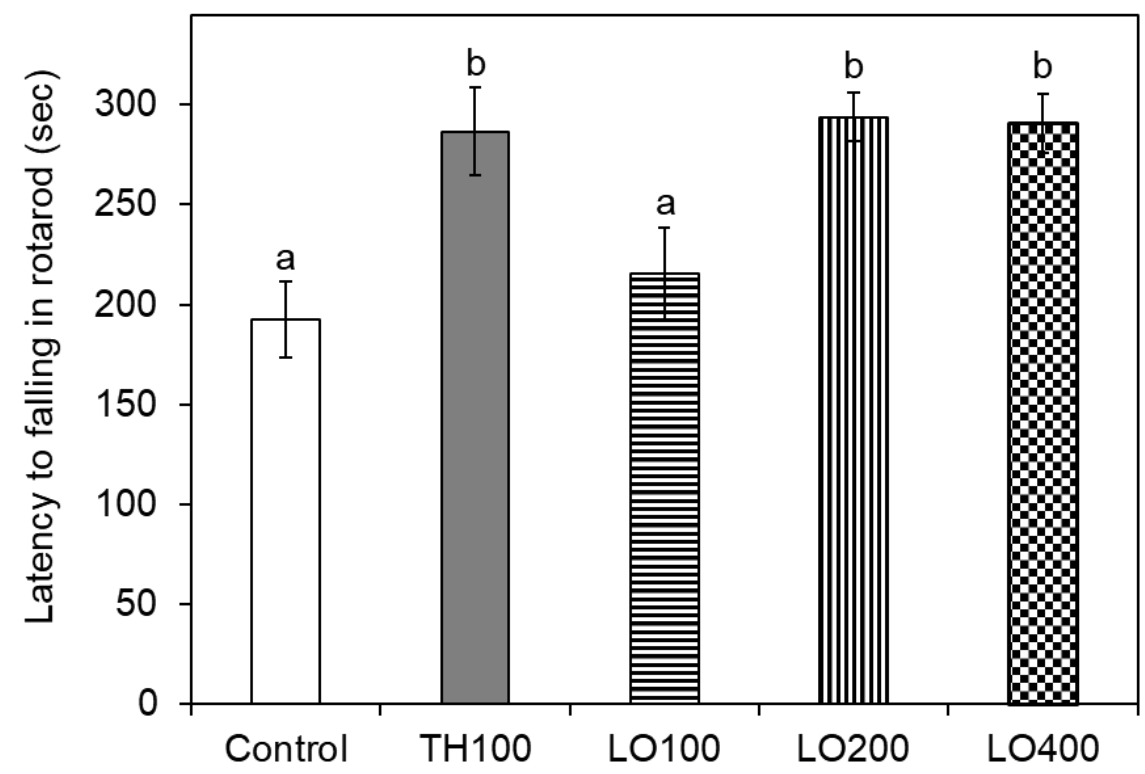

Figure 4. Effect of different doses of $C$. osmophloeum ct. linalool leaf oil on motor coordination in ICR mice by the rotarod assay. Data are presented as mean \pm S.D. $(n=7)$; TH100: trazodone hydrochloride, $100 \mathrm{mg} / \mathrm{Kg}$; LO100, LO200, and LO400: leaf oil, $100 \mathrm{mg} / \mathrm{Kg}, 200 \mathrm{mg} / \mathrm{Kg}$, and $400 \mathrm{mg} / \mathrm{Kg}$. Different letters $(\mathrm{a}-\mathrm{b})$ in the figure are significantly different at the level of $p<0.05$ according to the Scheffe's test.

Muthaiyah et al. (2014) reported that dietary walnuts can effectively improve the psychomotor coordination in a transgenic mouse model of Alzheimer's disease; it suggested dietary supplementation of natural products is of benefit to enhance the motor coordination skill [27]. Rekha et al. (2013) investigated the motor coordination effect of 
geraniol, an acyclic monoterpene alcohol; the results displayed that geraniol exhibited the neuroprotective effect to alleviate the chemically induced neurotoxicity and improve the motor coordination of treated mice in the rotarod assay [28]. Linalool is a structural isomer of geraniol; both compounds possess the double bond and alcoholic functional groups. The precise mechanism and neuroprotective effect of linalool need further investigation.

The above result reveals that the balance and motor activity of mice can be significantly enhanced through the inhalation of C. osmophloeum ct. linalool leaf oil. It is in accordance with previous findings from the locomotor behavioral and hypnotic effect evaluations. This is the first study to report the motor coordination activity of $C$. osmophloeum ct. linalool leaf oil.

\section{Materials and Methods}

\subsection{Hydrodistillation of Leaf Oil}

Fresh leaves $(22.78 \mathrm{Kg})$ of Cinnamomum osmophoeum Kanehira ct. linalool were harvested from the Taimalee Research Center of Taiwan Forestry Research Institute, Taitung, Taiwan. The identification of C. osmophoeum was authenticated in the Silviculture Division, Taiwan Forestry Research Institute by Dr. Cheng-Kuen Ho. Leaves were hydrodistilled in the conventional apparatus in batches to obtain total $176 \mathrm{~mL}$ of leaf essential oil, and the yield of leaf oil was ca. 3\%. Leaf oil was kept in dark glass bottles and stored in a refrigerator at $4{ }^{\circ} \mathrm{C}$.

\subsection{GC-MS Analysis of Leaf Oil}

The chemical constituents in leaf oils was analyzed by using the gas chromatographymass spectrometer (GC-MS, GCMS-QP2010 Ultra, Shimadzu, Kyoto, Japan) equipped with a DB-5MS capillary column (Crossbond 5\% phenyl methylpolysiloxane, 30 m length $\times$ $0.25 \mathrm{~mm}$ i.d. $\times 0.25 \mu \mathrm{m}$ film thickness, J\&W Scientific, Folsom, CA, USA). The temperature of the injection port was set at $250^{\circ} \mathrm{C}$. The oven temperature was initially held at $60^{\circ} \mathrm{C}$ for $3 \mathrm{~min}$, then increased to $150{ }^{\circ} \mathrm{C}$ at a rate of $3^{\circ} \mathrm{C} / \mathrm{min}$, and finally increased to $240{ }^{\circ} \mathrm{C}$ at a rate of $5{ }^{\circ} \mathrm{C} / \mathrm{min}$ and held for $5 \mathrm{~min}$. The carrier gas was helium at a flow rate of $1 \mathrm{~mL} / \mathrm{min}$, the split ratio was 1:10, and the GC/MS interface temperatures were set at $250{ }^{\circ} \mathrm{C}$. Constituents were identified by comparing mass spectra (m/z 50-650 amu) with the National Institute of Standards and Technology (NIST) and Wiley library databases, the arithmetic index (AI) [29], and authentic standards of constituents. The quantification of constituents was obtained by integrating the peak area of the chromatogram by GC coupled to a flame ionization detector (FID).

\subsection{Animals and Treatments}

Adults male ICR mice (weighing 30-38 g) were housed under constant room temperature $\left(22-25^{\circ} \mathrm{C}\right)$ and inverted light-dark cycle $(12: 12 \mathrm{~h})$ with free access to water and food ad libitum. The mice were allowed to adapt to the laboratory environment for 1 week and were randomly divided into five groups $(n=7)$. The leaf oil $(\mathrm{LO})$ was evenly mixed in soybean oil, and was administered daily by oral route (p.o.) via gavage to the animals at doses of 100, 200 and $400 \mathrm{mg} / \mathrm{kg}$, respectively, using soybean oil as the vehicle (control, soybean oil). The positive control was trazodone hydrochloride (TH, $100 \mathrm{mg} / \mathrm{kg}$ ), a prescription antidepressant approved by the FDA. Leaf oil and trazodone hydrochloride were administered each day over the whole experimental period. The body weight of each mouse was recorded once a week. After 2 weeks of treatment with leaf oil, behavioral tests were performed between 8 a.m. and 5 p.m. All behavioral protocols were approved by the Institutional Animal Care and Use Committee (IACUC) in National Taiwan University (IACUC Approval No: NTU105-EL-00088), and all mice were handled by the 3R principles of laboratory animal care and use. 


\subsection{Open Field Test (Antianxiety and Locomotor Behavioral Evaluation)}

The open field test is a classic assay used to evaluate the anxiety and locomotor activities in mice. One hour after oral administration, the mice were placed in the central zone of an open box $(60(\mathrm{~L}) \times 60(\mathrm{~W}) \times 40(\mathrm{H}) \mathrm{cm})$. The bottom area of the test box is divided into 16 square blocks, the middle 4 blocks is the central zone, the peripheral zone is 12 outer blocks. When the mouse enters the new environment, the mouse will spontaneously approach the outer perimeter near the wall area. A digital imaging system was used to analyze the number of entries in the central zone (antianxiety effect) and total travel distance (locomotor activity) during the $5 \mathrm{~min}$ of the test period [30-32].

\subsection{Forced Swimming Test (Antidepressant Behavioral Evaluation)}

According to the related studies [20,33-35], the essential oil was administered one hour before the forced swimming test (FST), the test mouse was individually placed in an open cylinder $(25 \mathrm{~cm}$ in high and $10 \mathrm{~cm}$ in diameter) with a water depth of $15 \mathrm{~cm}$ held at $25{ }^{\circ} \mathrm{C}$. A video camera was used to record each experimental process for $6 \mathrm{~min}$, and immobility time was defined as the time the mouse spent floating in the open cylinder without struggling and slightly treading to keep the head above water during the final $4 \mathrm{~min}$ of the test. The decrease in immobility time indicates the antidepressant-like behavior of treated mice.

\subsection{Tail Flick Test (Antinociceptive Behavioral Evaluation)}

After oral administration for $1 \mathrm{~h}$, the test mice were placed in the rodent restrainer, a plastic tube with ventilation. One-third of the tail of the test mouse were immersed in water at $50{ }^{\circ} \mathrm{C}$, and then the span of time in seconds was recorded as the tail of mouse was withdrawn from the hot water. When the span of time is more than $10 \mathrm{~s}$, it is recommended to quickly remove the mouse's tail from hot water to avoid injury to the mice. The longer span of time in the tail flick test reveals the better antinociceptive effect of the treatment [36-38].

\subsection{Primidone-Induced Sleeping Test (Hypnotic Effect Evaluation)}

Referring to the related studies [35,39], the primidone-induced sleeping test was conducted to evaluate the hypnotic effect of $C$. osmophloeum ct. linalool leaf oil in mice. After the oral administration of each treatment for $1 \mathrm{~h}$, primidone (an analog of phenobarbital) was injected into mice at a dose of $30 \mathrm{mg} / \mathrm{kg}$ (intraperitoneal injection, i.p.) to induce sleep. The duration of sleep of each mouse was recorded; the longer duration indicates the better hypnotic effect of the treatment.

\subsection{Rotarod Test (Motor Coordination Evaluation)}

Motor coordination activity was evaluated by the rotarod apparatus (LE8205, Panlab, 5 slots) consisting of rotating rods ( $3 \mathrm{~cm}$ in diameter). Referring to the related reports [40-42], all mice were pre-trained once for $5 \mathrm{~min}$ one day before the formal testing. After administering the specimens for $1 \mathrm{~h}$, the mice were placed in the rotarod, and the apparatus would automatically record the latency (duration of time spent on the rotating rod) when each mouse fell from the rod rotating at $10 \mathrm{rpm}$ in a 5-min test session. The longer latency time indicates the better motor coordination ability of the examined mice.

\subsection{Statistical Analysis}

All data were presented as mean values and standard deviations. The significance of difference was analyzed using the Scheffe's test, a completely post hoc multiple comparison analysis with stringent error control, of the SAS software (version 9.2, Cary, NC, USA) with a $95 \%$ confidence interval.

\section{Conclusions}

The study demonstrated the behavioral effects of C. osmophloeum ct. linalool leaf oil after oral administration in mice, the motor coordination and antidepressant activities of 
leaf oil were firstly reported by a rodent model system, to the best of our knowledge. In the open field test, the oral treatment on mice with leaf oil also increased the number of entries in the central zone and total travel distance; it provided evidence that the leaf oil exhibited anxiolytic and locomotor activities. The oral treatment on mice with leaf oil decreased the immobility time and induced the antidepressant effect in the forced swimming test. The motor coordination activity of mice was improved after the administration of leaf oil, and the time spent on the rotating rod of the treated mice was significantly increased in the rotarod assay. These results revealed that the C. osmophloeum ct. linalool leaf oil has antidepressant and anxiolytic activities, enhances the locomotor and motor coordination effects, and has the promising potential to be a therapeutic supplement of minor/medium depressive syndromes.

Author Contributions: Conceptualization, S.-T.C., C.-K.H. and H.-T.C.; Methodology, M.-L.C., C.-C.W. and F.-L.H.; Software, Y.-T.C.; Formal Analysis and Investigation, M.-L.C., Y.-T.C. and H.-T.C.; Writing and Editing, S.-T.C. and H.-T.C. All authors have read and agreed to the published version of the manuscript.

Funding: This research was funded by the Taiwan Forestry Research Institute (105-16.1.1-G2), Council of Agriculture, Executive Yuan, Taipei, Taiwan.

Institutional Review Board Statement: The study was conducted according to the 3R principles of laboratory animal care and use, and approved by the Institutional Animal Care and Use Committee (IACUC) in National Taiwan University (IACUC Approval No: NTU105-EL-00088).

Informed Consent Statement: Informed consent was obtained from all subjects involved in the study.

Data Availability Statement: The data are available from the corresponding author on reasonable request.

Acknowledgments: We thank the Taiwan Forestry Research Institute for the collection of plant material, and the Animal Resource Center, National Taiwan University, for the experimental support.

Conflicts of Interest: The authors declare no conflict of interest.

Sample Availability: Samples are available from the corresponding author.

\section{References}

1. Chang, S.T.; Chen, P.F.; Chang, S.C. Antibacterial activity of leaf essential oils and their constituents from Cinnamomum osmophloeum. J. Ethnopharmacol. 2001, 77, 123-127. [CrossRef]

2. Huang, C.Y.; Yeh, T.F.; Hsu, F.L.; Lin, C.Y.; Chang, S.T.; Chang, H.T. Xanthine oxidase inhibitory activity and thermostability of cinnamaldehyde-chemotype leaf oil of Cinnamomum osmophloeum microencapsulated with $\beta$-cyclodextrin. Molecules 2018, 23, 1107. [CrossRef] [PubMed]

3. Cheng, S.S.; Liu, J.Y.; Huang, C.G.; Hsui, Y.R.; Chen, W.J.; Chang, S.T. Insecticidal activities of leaf essential oils from Cinnamomum osmophloeum against three mosquito species. Bioresour. Technol. 2009, 100, 457-464. [CrossRef] [PubMed]

4. Wu, C.L.; Chang, H.T.; Hsui, Y.R.; Hsu, Y.W.; Liu, J.Y.; Wang, S.Y.; Chang, S.T. Antioxidant-enriched leaf water extracts of Cinnamomum osmophloeum from eleven provenances and their bioactive flavonoid glycosides. BioResources 2013, 8, 571-580. [CrossRef]

5. Cheng, B.H.; Sheen, L.Y.; Chang, S.T. Evaluation of anxiolytic potency of essential oil and S-(+)-linalool from Cinnamomum osmophloeum ct. linalool leaves in mice. J. Tradit. Complement. Med. 2015, 5, 27-34. [CrossRef] [PubMed]

6. Miller, A.L. St. John's Wort (Hypericum perforatum): Clinical effects on depression and other conditions. Altern. Med. Rev. 1998, 3, $18-26$.

7. Chatterjee, S.S.; Bhattacharya, S.K.; Wonnemann, M.; Singer, A.; Muller, W.E. Hyperforin as a possible antidepressant component of hypericum extracts. Life Sci. 1998, 63, 499-510. [CrossRef]

8. Butterweck, V.; Schmidt, M. St. John's wort: Role of active compounds for its mechanism of action and efficacy. Wien. Med. Wochenschr. 2007, 157, 356-361. [CrossRef] [PubMed]

9. Oliveira, A.I.; Pinho, C.; Sarmento, B.; Dias, A.C.P. Neuroprotective activity of Hypericum perforatum and its major components. Front. Plant Sci. 2016, 7, 1004. [CrossRef] [PubMed]

10. Forsdike, K.; Pirotta, M. St John's wort for depression: Scoping review about perceptions and use by general practitioners in clinical practice. J. Pharm. Pharmacol. 2019, 71, 117-128. [CrossRef]

11. Rahmati, B.; Kiasalari, Z.; Roghani, M.; Khalili, M.; Ansari, F. Antidepressant and anxiolytic activity of Lavandula officinalis aerial parts hydroalcoholic extract in scopolamine-treated rats. Pharm. Biol. 2017, 55, 958-965. [CrossRef] 
12. Hritcu, L.; Noumedem, J.; Cioanca, O.; Hancianu, M.; Postu, P.; Mihasan, M. Anxiolytic and antidepressant profile of the methanolic extract of Piper nigrum fruits in beta-amyloid (1-42) rat model of Alzheimer's disease. Behav. Brain Funct. 2015, 11, 13. [CrossRef] [PubMed]

13. Mannan, A.; Abir, A.B.; Rahman, R. Antidepressant-like effects of methanolic extract of Bacopa monniera in mice. BMC Complement. Altern. Med. 2015, 15, 337. [CrossRef] [PubMed]

14. Cassani, J.; Dorantes-Barron, A.M.; Novales, L.M.; Real, G.A.; Estrada-Reyes, R. Anti-depressant-like effect of kaempferitrin isolated from Justicia spicigera Schltdl (Acanthaceae) in two behavior models in mice: Evidence for the involvement of the serotonergic system. Molecules 2014, 19, 21442-21461. [CrossRef]

15. Jose Bagur, M.; Alonso Salinas, G.L.; Jimenez-Monreal, A.M.; Chaouqi, S.; Llorens, S.; Martinez-Tome, M.; Alonso, G.L. Saffron: An old medicinal plant and a potential novel functional food. Molecules 2017, 23, 30. [CrossRef] [PubMed]

16. Sarris, J.; Panossian, A.; Schweitzer, I.; Stough, C.; Scholey, A. Herbal medicine for depression, anxiety and insomnia: A review of psychopharmacology and clinical evidence. Eur. Neuropsychopharmacol. 2011, 21, 841-860. [CrossRef] [PubMed]

17. Hurley, L.L.; Akinfiresoye, L.; Nwulia, E.; Kamiya, A.; Kulkarni, A.; Tizabi, Y. Antidepressant-like effects of curcumin in WKY rat model of depression is associated with an increase in hippocampal BDNF. Behav. Brain Res. 2013, 239, 27-30. [CrossRef] [PubMed]

18. Hurley, L.L.; Akinfiresoye, L.; Kalejaiye, O.; Tizabi, Y. Antidepressant effects of resveratrol in an animal model of depression. Behav. Brain Res. 2014, 268, 1-7. [CrossRef]

19. Williams, J.W.; Mulrow, C.D.; Chiquette, E.; Noel, P.H.; Aguilar, C.; Cornell, J. A systematic review of newer pharmacotherapies for depression in adults: Evidence report summary. Ann. Intern. Med. 2000, 132, 743-756. [CrossRef] [PubMed]

20. Mahmoudi, M.; Ebrahimzadeh, M.A.; Abdi, M.; Arimi, Y.; Fathi, H. Antidepressant activities of Feijoa sellowiana fruit. Eur. Rev. Med. Pharmacol. Sci. 2015, 19, 2510-2513.

21. Mangolini, V.I.; Andrade, L.H.; Lotufo-Neto, F.; Wang, Y.P. Treatment of anxiety disorders in clinical practice: A critical overview of recent systematic evidence. Clinics 2019, 74, e1316. [CrossRef]

22. Linck, V.M.; Silva, A.L.; Figueiro, M.; Caramao, E.B.; Moreno, P.R.H.; Elisabetsky, E. Effects of inhaled linalool in anxiety, social interaction and aggressive behavior in mice. Phytomedicine 2010, 17, 679-683. [CrossRef]

23. Harada, H.; Kashiwadani, H.; Kanmura, Y.; Kuwaki, T. Linalool odor-induced anxiolytic effects in mice. Front. Behav. Neurosci. 2018, 23, 241. [CrossRef] [PubMed]

24. Caputo, L.; Reguilon, M.; Minarro, J.; De Feo, V.; Rodriguez-Arias, M. Lavandula angustifolia essential oil and linalool counteract social aversion induced by social defeat. Molecules 2018, 23, 2694. [CrossRef]

25. Maria, D.B.A.; Maria, V.V.R.; Lilian, M.N.; Lucia, M.M.; Oscar, G.P.; Rosa, E.R. Neurobehavioral and toxicological effects of an aqueous extract of Turnera diffusa Willd (Turneraceae) in mice. J. Ethnopharmacol. 2019, 236, 50-62. [CrossRef]

26. Rahimi, V.B.; Askari, V.; Tajani, A.; Hosseini, A.; Rakhshandeh, H. Evaluation of the sleep-prolonging effect of Lagenaria vulgaris and Cucurbita pepo extracts on pentobarbital-induced sleep and possible mechanisms of action. Medicina 2018, 54, 55. [CrossRef] [PubMed]

27. Muthaiyah, B.; Essa, M.M.; Lee, M.; Chauhan, V.; Kaur, K.; Chauhan, A. Dietary supplementation of walnuts improves memory deficits and learning skills in transgenic mouse model of Alzheimer's disease. J. Alzheimers Dis. 2014, 42, 1397-1405. [CrossRef]

28. Rekha, K.R.; Selvakumar, G.P.; Sethupathy, S.; Santha, K.; Sivakamasundari, R.I. Geraniol ameliorates the motor behavior and neurotrophic factors inadequacy in MPTP-induced mice model of Parkinson's disease. J. Mol. Neurosci. 2013, 51, 851-862. [CrossRef] [PubMed]

29. Adams, R.P. Identification of Essential Oil Components by Gas. Chromatography/Mass Spectrometry; Allured Publishing Corporation: Carol Stream, IL, USA, 2007; pp. 6-398. ISBN 978-1932633214.

30. Raghavendra, M.; Maiti, R.; Kumar, S.; Acharya, S. Role of aqueous extract of Azadirachta indica leaves in an experimental model of Alzheimer's disease in rats. Int. J. Appl. Basic Med. Res. 2013, 3, 37-47. [CrossRef] [PubMed]

31. Wanda, G.J.M.K.; Djiogue, S.; Gamo, F.Z.; Ngitedem, S.G.; Njamen, D. Anxiolytic and sedative activities of aqueous leaf extract of Dichrocephala integrifolia (Asteraceae) in mice. J. Ethnopharmacol. 2015, 176, 494-498. [CrossRef] [PubMed]

32. Panday, D.R.; Rauniar, G.P. Effect of root-extracts of Ficus benghalensis (Banyan) in memory, anxiety, muscle coordination and seizure in animal models. BMC Complement. Altern. Med. 2016, 16, 429. [CrossRef] [PubMed]

33. Vilela, F.C.; Padilha, M.M.; Alves-da-Silva, G.; Soncini, R.; Giusti-Paiva, A. Antidepressant-like activity of Sonchus oleraceus in mouse models of immobility tests. J. Med. Food 2010, 13, 219-222. [CrossRef] [PubMed]

34. Rojas, P.; Serrano-Garcia, N.; Medina-Campos, O.N.; Pedraza-Chaverri, J.; Ogren, S.O.; Rojas, C. Antidepressant-like effect of a Ginkgo biloba extract (EGb761) in the mouse forced swimming test: Role of oxidative stress. Neurochem. Int. 2011, 59, 628-636. [CrossRef] [PubMed]

35. Fajemiroye, J.O.; Galdino, P.M.; De Paula, J.A.; Rocha, F.F.; Akanmu, M.A.; Vanderlinde, F.A.; Zjawiony, J.K.; Costa, E.A. Anxiolytic and antidepressant like effects of natural food flavour (E)-methyl isoeugenol. Food Funct. 2014, 5, 1819-1828. [CrossRef] [PubMed]

36. Couto, V.M.; Vilela, F.C.; Dias, D.F.; Santos, M.H.; Soncini, R.; Nascimento, C.G.O.; Giusti-Paiva, A. Antinociceptive effect of extract of Emilia sonchifolia in mice. J. Ethnopharmacol. 2011, 134, 348-353. [CrossRef]

37. Jokinen, V.; Lilius, T.; Laitila, J.; Niemi, M.; Kambur, O.; Kalso, E.; Rauhala, P. Do diuretics have antinociceptive actions: Studies of spironolactone, eplerenone, furosemide and chlorothiazide, individually and with oxycodone and morphine. Basic Clin. Pharmacol. Toxicol. 2017, 120, 38-45. [CrossRef] [PubMed] 
38. Ali, B.H.; Bashir, A.K.; Tanira, M.O. Some effects of Cassia italica on the central nervous system in mice. J. Pharm. Pharmacol. 1997, 49, 500-504. [CrossRef] [PubMed]

39. Silva, M.I.; de Aquino Neto, M.R.; Teixeira Neto, P.F.; Moura, B.A.; do Amaral, J.F.; de Sousa, D.P.; Vasconcelos, S.M.; de Sousa, F.C. Central nervous system activity of acute administration of isopulegol in mice. Pharmacol. Biochem. Behav. 2007, 88, 141-147. [CrossRef]

40. Shiotsuki, H.; Yoshimi, K.; Shimo, Y.; Funayama, M.; Takamatsu, Y.; Ikeda, K.; Takahashi, R.; Kitazawa, S.; Hattori, N. A rotarod test for evaluation of motor skill learning. J. Neurosci. Methods 2010, 189, 180-185. [CrossRef] [PubMed]

41. Bridi, H.; Ccana-Ccapatinta, G.V.; Stolz, E.D.; Meirelles, G.C.; Bordignon, S.A.L.; Rates, S.M.K.; von Poser, G.L. Dimeric acylphloroglucinols from Hypericum austrobrasiliense exhibiting antinociceptive activity in mice. Phytochemistry 2016, 122, 178-183. [CrossRef]

42. Bisong, S.A.; Brown, R.; Osim, E.E. Comparative effects of Rauwolfia vomitoria and chlorpromazine on locomotor behaviour and anxiety in mice. J. Ethnopharmacol. 2010, 132, 334-339. [CrossRef] [PubMed] 